\title{
Study of reactivity of $p$-cymene ruthenium(II) dimer towards diphenyl-2-pyridylphosphine: Synthesis, characterization and molecular structures of $\left[\left(\eta^{6}-p\right.\right.$-cymene $\left.) \operatorname{RuCl}_{2}\left(\mathrm{PPh}_{2} \mathbf{P y}\right)\right]$ and $\left[\left(\eta^{6}-p\right.\right.$-cymene $\left.) \operatorname{RuCl}\left(\mathbf{P P h}_{2} \mathbf{P y}\right)\right] \mathrm{BF}_{4}$
}

\author{
R LALREMPUIA $^{1}$, PATRICK J CARROLL ${ }^{2}$ and MOHAN RAO KOLLIPARA ${ }^{1, * *}$ \\ ${ }^{1}$ Department of Chemistry, North Eastern Hill University, Shillong 793 022, India \\ ${ }^{2}$ Department of Chemistry, University of Pennsylvania, Philadelphia, PA-19104, USA \\ e-mail:kmrao@nehu.ac.in
}

MS received 31 March 2003; revised 8 September 2003

\begin{abstract}
The reaction of $\left[\left\{\left(\eta^{6}-p \text {-cymene }\right) \mathrm{Ru}(\mu \mathrm{HCl})\right\}_{2} \mathrm{Cl}_{2}\right]$ with functionalized phosphine viz, diphenyl2-pyridylphosphine yielded complexes of the type: (a) P-bonded complex [( $\eta^{6}-p$-cymene $\left.) \mathrm{RuCl}_{2}\left(\mathrm{PPh}_{2} \mathrm{Py}\right)\right]$ (1), (b) P-, N-chelated complex $\left[\left(\eta^{6}-p\right.\right.$-cymene $\left.) \mathrm{RuCl}-\left(\mathrm{PPh}_{2} \mathrm{Py}\right)\right] \mathrm{BF}_{4}$ (2) and $\left[\mathrm{RuCl}_{2}\left(\mathrm{PPh}_{2} \mathrm{Py}\right)_{2}\right]$ (3) resulting from the displacement of the $p$-cymene ligand. These complexes were characterized by ${ }^{1} \mathrm{H} \mathrm{NMR}^{\mathrm{N}} \mathrm{P}$ NMR and analytical data. The structures of complexes $\mathbf{1}$ and $\mathbf{2}$ have been confirmed by single crystal X-ray diffraction study. Complex 1 crystallised in triclinic space group $P \overline{1}$ with $a=10.9403$ (3) $\AA$, $b=13.3108$ (3) $\AA, c=10.5394$ (10) $\AA, \alpha=88.943(2)^{\circ}, \beta=117.193 \quad(2)^{\circ}, \quad \gamma=113.1680 \quad(10)^{\circ}, Z=2$ and $V=1230 \cdot 39$ (5) $\AA^{3}$. The complex 2 crystallises in monoclinic space group $P 2_{1}$ with $a=9 \cdot 1738$ (4) $\AA, b=$ 14.0650 (6) $\mathrm{s}, c=10 \cdot 7453$ (5) $\AA, \beta=106 \cdot 809(1)^{\circ}, Z=2$ and $V=1327 \cdot 22(10) \AA^{3}$.
\end{abstract}

Keywords. Ruthenium; diphenyl-2-pyridylphosphine; p-cymene; X-ray crystallography.

\section{Introduction}

Arene ruthenium(II) complexes have been the subjects of intense research in the field of organometallic chemistry during recent years. ${ }^{1}$ The catalytic activity of these complexes ranges from hydrogen transfer ${ }^{2}$ to ring-closing metathesis. ${ }^{3}$ Anti tumour activities exhibited by some water-soluble arene ruthenium(II) complexes has also evoked interest in recent years. ${ }^{4}$

We have been interested in the synthesis of arene ruthenium(II) complexes keeping in mind their possible catalytic activity. Pyridylphosphines, in general, continue to induce much interest as being excellent ligands for stabilizing many transitionmetal co-ordinations and organometallic complexes. ${ }^{5}$ Diphenyl-2-pyridylphosphine $\left(\mathrm{PPh}_{2} \mathrm{Py}\right)$ displays numerous ligating modes ranging from $\mathrm{P}$ coordination, ${ }^{6} \mathrm{P}-, \mathrm{N}-$ chelation $^{7}$ and more commonly, P-, Nbridging between two metal centers. ${ }^{8}$ In this paper, we would like to report the synthesis of new com-

*For correspondence plexes where diphenyl 2-pyridylphosphine exhibits bonding modes through (i) $\mathrm{P}$ coordination $\left[\left(\eta^{6}-p\right.\right.$ cymene) $\left.\mathrm{RuCl}_{2}\left(\mathrm{PPh}_{2} \mathrm{Py}\right)\right]$ (1), (ii) $\mathrm{P}-, \mathrm{N}$-chelating $\left[\left(\eta^{6}-\right.\right.$ $p$-cymene $\left.) \mathrm{RuCl}\left(\mathrm{PPh}_{2} \mathrm{Py}\right)\right] \mathrm{BF}_{4}$ (2) and $\left[\mathrm{RuCl}_{2}\left(\mathrm{PPh}_{2}\right.\right.$ $\left.\mathrm{Py})_{2}\right]$, (3). Complex $\mathbf{3}$ resulted from the displacement of the cymene ligand from the starting dimer. In order to establish the exact structures, X-ray crystallographic analysis has been carried out for complexes $\mathbf{1}$ and $\mathbf{2}$.

\section{Experimental section}

All chemicals used were of reagent grade. All reactions were carried out in purified and dried solvents. ${ }^{1} \mathrm{H}$ NMR spectra were recorded on a Brucker ACF 300 spectrometer. Infrared spectra were taken on a Perkin-Elmer model 983 spectrophotometer using CsI pellets. Elemental analysis was performed in Perkin-Elmer-2400 CHNS/O analyzer. Diphenyl-2pyridylphosphine $\left(\mathrm{PPh}_{2} \mathrm{Py}\right)$ was purchased from Aldrich and used as such. [\{ $\left(\eta^{6}-p\right.$-cymene $) \operatorname{Ru}(\mu$ $\mathrm{Cl})\}_{2} \mathrm{Cl}_{2}$ ] was prepared according to the literature method. ${ }^{9}$ 
2.1 Synthesis of $\left[\left(\eta^{6}-p\right.\right.$-cymene $\left.) \mathrm{RuCl}_{2}\left(\mathrm{PPh}_{2} \mathrm{Py}\right)\right]$ (1)

Diphenyl-2-pyridylphosphine $\quad(0.043 \mathrm{~g}, \quad 0.163 \mathrm{mmol})$ was added to a dichloromethane solution $(10 \mathrm{ml})$ of the complex $\left[\left\{\left(\eta^{6}-p \text {-cymene }\right) \mathrm{Ru}(\mu-\mathrm{Cl})\right\}_{2} \mathrm{Cl}_{2}\right](0 \cdot 100 \mathrm{~g}$, $0.163 \mathrm{mmol}$ ) and the resulting solution was stirred at room temperature for $1 \mathrm{~h}$. The solvent was reduced to about $2 \mathrm{ml}$ and addition of excess diethylether with vigorous stirring gave the product as a microcrystalline red solid. Yield: 0.148 g, 80\%.

Analysis: Calc. for $\mathrm{C}_{27} \mathrm{H}_{28} \mathrm{NPRuC}_{12}: \mathrm{C}, 56.98 ; \mathrm{H}$, $4.92 ; \mathrm{N}, 2.46 \%$. Found C, 56.94; H, 5.10; N, $2.49 \%$.

${ }^{1} \mathrm{H}-\mathrm{NMR}\left(\mathrm{CDCl}_{3}, \mathrm{ppm}\right): 8.85\left(d, J_{H H}=4.5 \mathrm{~Hz}, 1 \mathrm{H}\right)$, 8.03-7.96 $(m, 4 \mathrm{H}), 7.56-7.11(m, 9 \mathrm{H}), 5.45(d$, $\left.J_{H H}=6.3 \mathrm{~Hz}, 2 \mathrm{H}\right), 5.32\left(d, J_{H H}=6.3 \mathrm{~Hz}, 2 \mathrm{H}\right), 2.59$ (sept, 1H), $1.68(s, 3 \mathrm{H}), 0.93\left(d, J_{H H}=6.6 \mathrm{~Hz}, 6 \mathrm{H}\right)$.

${ }^{31} \mathrm{P}\left\{{ }^{\mathrm{I}} \mathrm{H}\right\}$ NMR $\left(\mathrm{CDCl}_{3}, \mathrm{ppm}\right): 21 \cdot 41(s)$.

IR (CsI pellet, $\left.\mathrm{cm}^{-1}\right)$ : $288\left(v_{\mathrm{Ru}-\mathrm{Cl}}\right)$.

2.2 Synthesis of $\left[\left(\eta^{6}-p\right.\right.$-cymene $\left.) R u C l\left(P P h_{2} P y\right)\right] B F_{4}$ (2) and $\left[\mathrm{RuCl}_{2}\left(\mathrm{PPh}_{2} \mathrm{Py}\right)_{2}\right](\mathbf{3})$

The mixture of $\left[\left\{\left(\eta^{6}-p \text {-cymene }\right) \mathrm{Ru}(\mu-\mathrm{Cl})\right\}_{2} \mathrm{Cl}_{2}\right]$ $(0.100 \mathrm{~g}, \quad 0.163 \mathrm{mmol}), \quad$ diphenyl-2-pyridylphosphine $(0.214 \mathrm{~g}, \quad 0.815 \mathrm{mmol})$ and $\mathrm{NH}_{4} \mathrm{BF}_{4} \quad(0.085 \mathrm{~g}$, $0.78 \mathrm{mmol})$ were refluxed in methanol $(25 \mathrm{ml})$. The colour of the solution immediately changed to orange, with some red solid material left at the bottom of the flask, which completely dissolved after refluxing for $3 \mathrm{~h}$ to give yellow solution. The solution was then rotary evaporated, extracted with acetone and filtered through a short silica gel column to remove insoluble material. Recrystallisation of the crude product from a mixture of acetone and hexane yielded complex (2) as red and complex (3) as yellow crystals. These were separated by physical methods.

2.2a Complex 2: Analysis of calc. for $\mathrm{C}_{27} \mathrm{H}_{28} \mathrm{BClF}_{4} \mathrm{NPRu}: \mathrm{C}, 52 \cdot 25 ; \mathrm{H}, 4 \cdot 57 ; \mathrm{N}, 2.26 \%$. Found: C, 52.34; H, 4.78; N, 2.32\%.

${ }^{1} \mathrm{H}$ NMR $\left(\mathrm{CDCl}_{3}, \mathrm{ppm}\right): 9.10\left(d, J_{H H}=5.4 \mathrm{~Hz}, 1 \mathrm{H}\right)$, 8.24-8.18 (m, 2H), 8.01-7.85 (m, 5H), 7.61-7.44 (m, $6 \mathrm{H}), \quad 6.12 \quad\left(t, \quad J_{H H}=6.3 \mathrm{~Hz}, \quad 2 \mathrm{H}\right), \quad 5.90 \quad(d$, $\left.J_{H H}=6.0 \mathrm{~Hz}, 1 \mathrm{H}\right), 5.58\left(d, J_{H H}=6.0 \mathrm{~Hz}, 1 \mathrm{H}\right), 2.57$ (sept, 1H), $1.97(s, 3 \mathrm{H}), 1.16\left(d, J_{H H}=6.9 \mathrm{~Hz}, 3 \mathrm{H}\right)$, $1.05\left(d, J_{H H}=7.2 \mathrm{~Hz}, 3 \mathrm{H}\right)$.

${ }^{31} \mathrm{P}\left\{{ }^{\mathrm{I}} \mathrm{H}\right\}$ NMR: $-11.72(s)$.

IR (CsI pellet, $\left.\mathrm{cm}^{-1}\right)$ : $283\left(v_{\mathrm{Ru}-\mathrm{Cl}}\right)$. 2.2b Complex 3: Analysis of calc. for $\mathrm{C}_{34} \mathrm{H}_{28} \mathrm{Cl}_{2} \mathrm{Ru}$ : C, 58.46; H, 4.04; N, 4.00\%; Found: C, 58.50; H, 4.25; N, 4.16\%.

${ }^{1} \mathrm{H}$ NMR $\left(\mathrm{CDCl}_{3}, \mathrm{ppm}\right): 8.55\left(d, J_{H H}=0.3 \mathrm{~Hz}, 1 \mathrm{H}\right)$, $8.32\left(t, \quad J_{H H}=7.5 \mathrm{~Hz}, 1 \mathrm{H}\right), 8.02\left(d, J_{H H}=7.8 \mathrm{~Hz}\right.$, $1 \mathrm{H}), 7.86\left(t, J_{H H}=6.0 \mathrm{~Hz}, 1 \mathrm{H}\right), 7.68\left(t, J_{H H}=7.5 \mathrm{~Hz}\right.$, $1 \mathrm{H}), 7.52-7.37(m, 5 \mathrm{H}), 7 \cdot 17\left(t, J_{H H}=7.2 \mathrm{~Hz}, 2 \mathrm{H}\right)$, and $6.79(m, 2 \mathrm{H})$.

${ }^{31} \mathrm{P}\left\{{ }^{\mathrm{I}} \mathrm{H}\right\}$ NMR: $1.50(s)$.

IR $\left(\mathrm{CsI}, \mathrm{cm}^{-1}\right): 280\left(\mathrm{v}_{\mathrm{Ru}-\mathrm{Cl}}\right)$.

2.2c Method 2-Synthesis of [ $\left(\eta^{6}\right.$-p-cymene $)$ $\mathrm{RuCl}\left(\mathrm{PPh}_{2} \mathrm{Py}\right) \mathrm{BBF}_{4}(\mathbf{2})$ : A mixture of the complex [( $\eta^{6}$-cymene $\left.) \mathrm{RuCl}_{2}\left(\mathrm{PPh}_{2} \mathrm{Py}\right)\right](\mathbf{1})(0 \cdot 100 \mathrm{~g}, 0.161 \mathrm{mmol})$ and $\mathrm{NH}_{4} \mathrm{BF}_{4} \quad(0.042 \mathrm{~g}, \quad 0.40 \mathrm{mmol})$ in methanol $(15 \mathrm{ml})$ was stirred at room temperature for $5 \mathrm{~h}$. The clear orange-coloured solution was then rotary evaporated. The residue was extracted with acetone and filtered to remove insoluble material. The filtrate was then reduced to about $1 \mathrm{ml}$ and addition of excess hexane gave orange solid. Yield: $0.085 \mathrm{~g}$, $84 \%$.

\section{$2.3 X$ X-ray crystallographic analysis for complexes $\mathbf{1}$ and $\mathbf{2}$}

Single crystals suitable for X-ray analysis were grown from dichloromethane/diethylether (complex 1) and acetone/hexane (complex 2). X-ray intensity data were collected on a Rigaku $R$-Axis IIc (Rigaku Mercury CCD for complex 2) area detector employing graphite-monochromated $\mathrm{Mo}-\mathrm{K}_{\alpha}$ radiation $(\lambda=$ $0.71069 \AA$ ). Indexing was performed from a series of $1^{\circ}$ oscillation images with exposures of $200 \mathrm{sec}-$ onds per frame. A hemisphere of data was collected using $6^{\circ}$ oscillation angles with exposures of 150 seconds per frame and a crystal-to-detector distance of $82 \mathrm{~mm}$. Oscillation images were processed using bioteX, ${ }^{10}$ producing a listing of unaveraged $F^{2}$ and $\sigma\left(F^{2}\right)$ values which were then passed to the teX$\operatorname{san}^{11}$ program package for further processing and structure solution on a Silicon Graphics O2 computer. The intensity data were corrected for Lorentz and polarization effects but not for absorption.

The structures were solved by direct methods $\left(\right.$ SIR92 $\left.^{12}\right)$. Refinement was by full-matrix least squares based on $F^{2}$ using SHELXL-93. ${ }^{13}$ All reflections were used during refinement $\left(F^{2}\right.$ 's that were experimentally negative were replaced by $F^{2}=0$ ). The weighting scheme used was $w=1 /$ 
$\left[\sigma^{2}\left(F_{0}^{2}\right)+0.0682 P^{2}+0.8632 P\right]$, where $P=\left(F_{0}^{2}+2 F_{c}^{2}\right) / 3$. Non-hydrogen atoms were refined anisotropically and hydrogen atoms were refined using a 'riding' model. Refinement for complex 1 converged to $R_{1}=0.0416$ and $w R_{2}=0.1089$ for 5351 reflections for which $F>4 \sigma(F)$ and $R_{1}=0.0436, w R_{2}=0.1110$ and $\mathrm{GOF}=1.074$ for all 5589 unique, nonzero reflections and 293 variables. Refinement for complex 2 converged to $R_{1}=0.0338$ and $w R_{2}=$ 0.0913 for 12916 reflections for which $F>4 \sigma(F)$ and $R_{1}=0.0347, w R_{2}=0.0927$ and $\mathrm{GOF}=1.090$ for all 13124 unique, non-zero reflections and 329 variables.

Table 1 lists cell information, data collection parameters, and refinement data. Tables 2 and 3 list bond distances and bond angles of compounds 1 and 2 respectively. Figures 1 and 2 are ORTEP ${ }^{14}$ representations of the molecule with $30 \%$ probability thermal ellipsoids displayed.

\section{Results and discussion}

The dinuclear complex $\left[\left\{\left(\eta^{6}-p \text {-cymene }\right) \mathrm{Ru}(\mu-\mathrm{Cl})\right\}_{2}\right.$ $\mathrm{Cl}_{2}$ ] undergoes bridge cleavage reaction with diphenyl-2-pyridylphosphine yielding neutral P-bonded, cationic P-, N-chelating and neutral P-, N-chelating complexes respectively.

The reaction of $\left[\left\{\left(\eta^{6}-p \text {-cymene }\right) \mathrm{Ru}(\mu-\mathrm{Cl})\right\}_{2} \mathrm{Cl}_{2}\right]$ with one equivalent of the ligand in dichloro-

Table 1. Summary of structure determination of complexes $\mathbf{1}$ and $\mathbf{2}^{\mathrm{a}}$.

\begin{tabular}{|c|c|c|}
\hline Formula & $\mathrm{RuC}_{27} \mathrm{H}_{28} \mathrm{NPCl}_{2}$ & $\mathrm{RuC}_{27} \mathrm{BH}_{28} \mathrm{NPF}_{4} \mathrm{Cl}$ \\
\hline Formula weight & 569.44 & $620 \cdot 80$ \\
\hline Crystal class & Triclinic & Monoclinic \\
\hline Space group & $P 1(\# 2)$ & $P 2_{1}(\# 4)$ \\
\hline$Z$ & 2 & 2 \\
\hline \multicolumn{3}{|l|}{ Cell constants } \\
\hline$a$ & $10 \cdot 9403(3) \AA$ & $9 \cdot 1738(4) \AA$ \\
\hline$b$ & $13 \cdot 3108(3) \AA$ & $14 \cdot 0650(6) \AA$ \\
\hline$c$ & $10 \cdot 53940(10) \AA$ & $10 \cdot 7453(5) \AA$ \\
\hline$\alpha$ & $88.943(2)^{\circ}$ & \\
\hline$\beta$ & $117 \cdot 193(2)^{\circ}$ & $106 \cdot 809(1)^{\circ}$ \\
\hline$\gamma$ & $113 \cdot 1680(10)^{\circ}$ & \\
\hline$V^{\circ}$ & $1230 \cdot 39(5) \AA$ & $1327 \cdot 22(10) \AA$ \\
\hline$\mu$ & $9.35 \mathrm{~cm}^{-1}$ & $7.97 \mathrm{~cm}^{-1}$ \\
\hline Crystal size (mm) & $0.30 \times 0.25 \times 0.25$ & $0.27 \times 0.25 \times 0.24$ \\
\hline$D_{\text {calc }}$ & $1.537 \mathrm{~g} / \mathrm{cm}^{3}$ & $1.553 \mathrm{~g} / \mathrm{cm}^{3}$ \\
\hline$F(000)$ & 580 & 628 \\
\hline Radiation & Mo-K $\alpha(\lambda=0.71069 \AA$ & Mo-K $\alpha(\lambda=0.71069 \AA$ \\
\hline $2 \theta$ range & $5 \cdot 02-54.98^{\circ}$ & $3.96-58.24^{\circ}$ \\
\hline \multirow[t]{2}{*}{$h k l$ collected } & $-14 \leq h \leq 14$ & $-10 \leq h \leq 11$ \\
\hline & $\begin{array}{l}-16 \leq k \leq 17 \\
-13 \leq l \leq 13\end{array}$ & $\begin{array}{l}-19 \leq k \leq 19 \\
-14 \leq l \leq 14\end{array}$ \\
\hline No. of reflections measured & 19788 & 13124 \\
\hline No. of unique reflections & $5589\left(R_{\mathrm{int}}=0.0254\right)$ & $13124\left(R_{\mathrm{int}}=0 \cdot 0000\right)$ \\
\hline No. of observed reflections & $5351(F>4 \sigma)$ & $12916(F>4 \sigma)$ \\
\hline No. of reflections used in refinement & 5589 & 13124 \\
\hline No. of parameters & 293 & 329 \\
\hline \multirow[t]{2}{*}{$R$ indices $(F>4 \sigma)$} & $R_{1}=0.0416$ & $R_{1}=0.0338$ \\
\hline & $w R_{2}=0 \cdot 1089$ & $w R_{2}=0.0913$ \\
\hline \multirow[t]{2}{*}{$R$ indices (all data) } & $R_{1}=0.0436$ & $R_{1}=0.0347$ \\
\hline & $w R_{2}=0 \cdot 1110$ & $w R_{2}=0.0927$ \\
\hline $\mathrm{GOF}^{\#}:$ & 1.074 & 1.090 \\
\hline Final difference peaks $\left(e / \AA^{3}\right)$ & $+0 \cdot 701,-0 \cdot 707$ & $+0 \cdot 799,-0.809$ \\
\hline \multicolumn{3}{|c|}{$\begin{array}{l}{ }^{\#} R_{1}=F_{0}|-| F_{c} \||| F_{0} \mid, \quad w R_{2}=\left\{w\left(F_{0}^{2}-F_{c}^{2}\right)^{2} / w\left(F_{0}^{2}\right)^{2}\right\}^{1 / 2}, \quad \mathrm{GOF}=\left\{w\left(F_{0}^{2}-F_{c}^{2}\right)^{2} /(n-p)\right\}^{1 / 2}, \\
\text { where } n=\text { the number of reflections and } p=\text { the number of parameters refined. } \\
{ }^{\mathrm{a}} \text { The crystal of complex } 2 \text { was found to be twinned by a rotation of } 180^{\circ} \text { about the normal to } \\
30 \overline{1} \text { (twin indexing and processing of twinned data was performed by the TwinSolve }{ }^{\mathrm{b}} \\
\text { module of crystal Clear). }\end{array}$} \\
\hline
\end{tabular}


Table 2. Selected bond lengths $(\AA)$ and angles $\left({ }^{\circ}\right)$ for complex $\mathbf{1}$.

\begin{tabular}{|c|c|c|c|c|c|}
\hline \multicolumn{6}{|l|}{ Bond lengths $(\AA)$} \\
\hline $\mathrm{Ru}-\mathrm{C} 23$ & $2 \cdot 160(3)$ & $\mathrm{Ru}-\mathrm{Cl1}$ & $2 \cdot 4111(8)$ & & \\
\hline $\mathrm{Ru}-\mathrm{C} 19$ & $2 \cdot 238(3)$ & C19-C20 & $1 \cdot 426(4)$ & & \\
\hline $\mathrm{Ru}-\mathrm{P} 1$ & $2 \cdot 3565(7)$ & $\mathrm{C} 22-\mathrm{C} 23$ & $1.405(4)$ & & \\
\hline $\mathrm{C} 19-\mathrm{C} 24$ & $1.400(4)$ & $\mathrm{Ru}-\mathrm{C} 22$ & $2 \cdot 217(3)$ & & \\
\hline $\mathrm{C} 21-\mathrm{C} 22$ & $1.431(5)$ & $\mathrm{Ru}-\mathrm{C} 20$ & $2 \cdot 251(3)$ & & \\
\hline $\mathrm{Ru}-\mathrm{C} 24$ & $2 \cdot 183(3)$ & $\mathrm{C} 20-\mathrm{C} 21$ & $1 \cdot 378(5)$ & & \\
\hline $\mathrm{Ru}-\mathrm{C} 21$ & $2 \cdot 240(3)$ & $\mathrm{C} 23-\mathrm{C} 24$ & $1 \cdot 430(4)$ & & \\
\hline $\mathrm{Ru}-\mathrm{Cl} 2$ & $2 \cdot 4107(7)$ & & & & \\
\hline \multicolumn{6}{|l|}{ Bond angles $\left(^{\circ}\right)$} \\
\hline $\mathrm{C} 23-\mathrm{Ru}-\mathrm{P} 1$ & $88.99(8)$ & $\mathrm{C} 24-\mathrm{Ru}-\mathrm{P} 1$ & $94 \cdot 41(8)$ & $\mathrm{C} 22-\mathrm{Ru}-\mathrm{P} 1$ & $112 \cdot 04(9)$ \\
\hline $\mathrm{C} 19-\mathrm{Ru}-\mathrm{P} 1$ & $123 \cdot 52(9)$ & $\mathrm{C} 21-\mathrm{Ru}-\mathrm{P} 1$ & $149 \cdot 18(10)$ & $\mathrm{C} 20-\mathrm{Ru}-\mathrm{P} 1$ & 160.07(9) \\
\hline $\mathrm{C} 23-\mathrm{Ru}-\mathrm{Cl} 2$ & $119 \cdot 59(8)$ & $\mathrm{C} 24-\mathrm{Ru}-\mathrm{Cl} 2$ & $158 \cdot 00(8)$ & $\mathrm{C} 22-\mathrm{Ru}-\mathrm{Cl} 2$ & $91 \cdot 60(8)$ \\
\hline $\mathrm{C} 19-\mathrm{Ru}-\mathrm{Cl} 2$ & $151 \cdot 57(9)$ & $\mathrm{C} 21-\mathrm{Ru}-\mathrm{Cl} 2$ & $90 \cdot 84(9)$ & $\mathrm{C} 20-\mathrm{Ru}-\mathrm{Cl} 2$ & $114 \cdot 86(9)$ \\
\hline $\mathrm{P} 1-\mathrm{Ru}-\mathrm{Cl} 2$ & $84 \cdot 83(3)$ & $\mathrm{C} 23-\mathrm{Ru}-\mathrm{C} 11$ & $150 \cdot 85(9)$ & $\mathrm{C} 24-\mathrm{Ru}-\mathrm{Cl1}$ & $112 \cdot 59(8)$ \\
\hline $\mathrm{C} 22-\mathrm{Ru}-\mathrm{Cl1}$ & 157.04(9) & $\mathrm{C} 19-\mathrm{Ru}-\mathrm{Cl1}$ & $88 \cdot 18(8)$ & $\mathrm{C} 21-\mathrm{Ru}-\mathrm{Cl} 1$ & $119 \cdot 61(10)$ \\
\hline $\mathrm{C} 20-\mathrm{Ru}-\mathrm{Cl1}$ & $92 \cdot 26(9)$ & $\mathrm{P} 1-\mathrm{Ru}-\mathrm{Cl1}$ & $90 \cdot 90(3)$ & $\mathrm{Cl} 2-\mathrm{Ru}-\mathrm{Cl} 1$ & $89 \cdot 41(3)$ \\
\hline
\end{tabular}

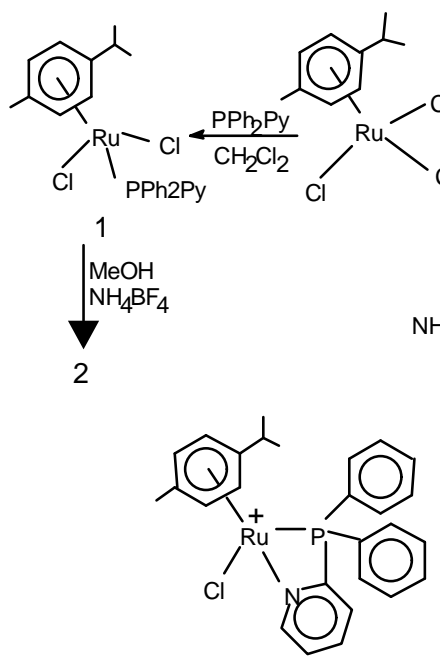

2

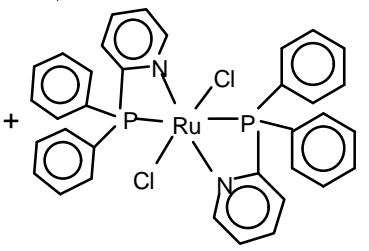

3 methane yielded stable neutral complex $\left[\left(\eta^{6}-p\right.\right.$ cymene) $\left.\mathrm{RuCl}_{2}\left(\mathrm{PPh}_{2} \mathrm{Py}\right)\right]$ (1) which is soluble in most of the polar solvents. The spectroscopic data clearly suggest the coordination of the ligand to the metal as evidence from the shift of the phosphorus and protons resonance as compared to the starting materials, but of course without any certain assignment through which atom is bonded to the metal. ${ }^{1} \mathrm{H}$ NMR spectrum of the complex 1 shows resonance for the phosphine ligand in the aromatic region in the range of $8.85-7.11 \mathrm{ppm}$. The $p$-cymene signals are well-resolved and exhibit only $\mathrm{H}-\mathrm{H}$ coupling.

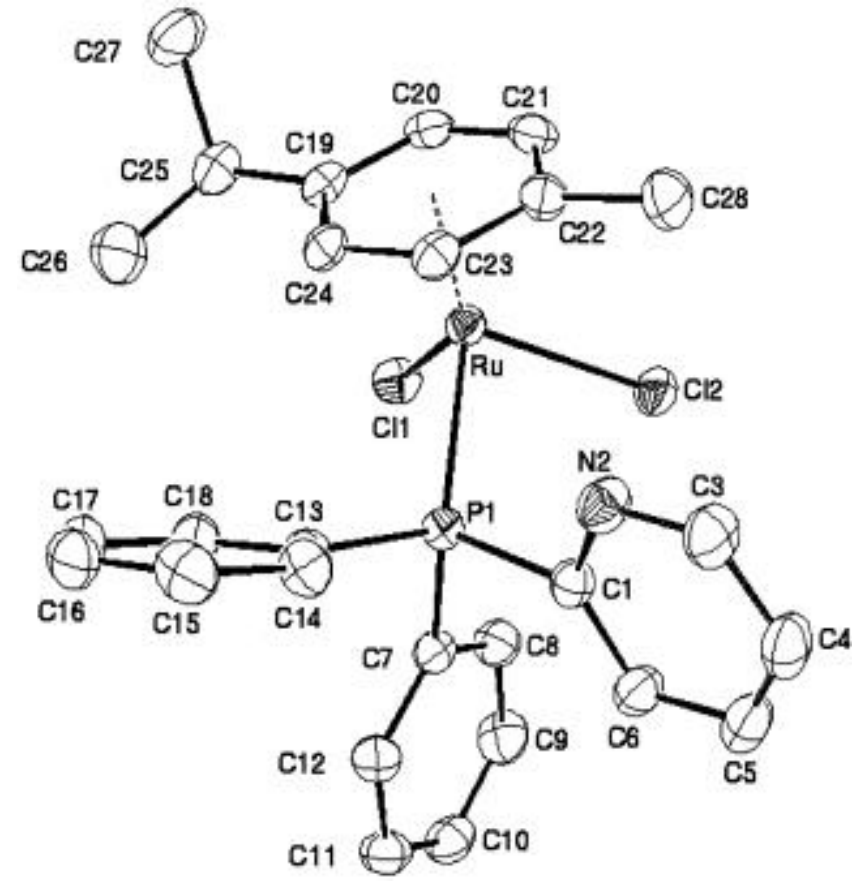

Figure 1. Molecular structure of complex $\left[\left(\eta^{6}-p-\right.\right.$ cymene) $\left.\mathrm{RuCl}_{2}\left(\mathrm{PPh}_{2} \mathrm{Py}\right)\right]$ (1).

The arene ring protons appear as two sets of doublets at 5.45 and $5.52 \mathrm{ppm}$ while a septet is observed for $\underline{\mathrm{HC}}(\mathrm{Me})_{2}$, as found in other $p$-cymene ruthenium complexes. The water peak from the deutero chloroform solvent obscured $\mathrm{CH}_{3}$ signal $(\sim 1.6 \mathrm{ppm})$. The 
Table 3. Selected bond lengths $(\AA)$ and bond angles $\left({ }^{\circ}\right)$ for complex 2 .

\begin{tabular}{llll}
\hline Bond lengths $(\AA)$ & & & \\
& & & \\
$\mathrm{Ru}-\mathrm{N} 2$ & $2 \cdot 104(2)$ & $\mathrm{Ru}-\mathrm{C} 23$ & $2 \cdot 166(3)$ \\
$\mathrm{Ru}-\mathrm{C} 22$ & $2 \cdot 207(3)$ & $\mathrm{Ru}-\mathrm{C} 21$ & $2 \cdot 227(3)$ \\
$\mathrm{Ru}-\mathrm{C} 20$ & $2 \cdot 241(3)$ & $\mathrm{Ru}-\mathrm{P}$ & $2 \cdot 3311(7)$ \\
$\mathrm{Ru}-\mathrm{C} 24$ & $2 \cdot 204(3)$ & $\mathrm{P}-\mathrm{C} 1$ & $1 \cdot 826(3)$ \\
$\mathrm{Ru}-\mathrm{C} 19$ & $2 \cdot 229(3)$ & $\mathrm{C} 1-\mathrm{C} 6$ & $1 \cdot 384(4)$ \\
$\mathrm{Ru}-\mathrm{Cl}$ & $2 \cdot 3970(8)$ & $\mathrm{C} 5-\mathrm{C} 6$ & $1 \cdot 399(5)$ \\
$\mathrm{P}-\mathrm{C} 13$ & $1 \cdot 809(3)$ & $\mathrm{P}-\mathrm{C} 7$ & $1 \cdot 812(3)$ \\
$\mathrm{N} 2-\mathrm{C} 1$ & $1 \cdot 351(4)$ & $\mathrm{N} 2-\mathrm{C} 3$ & $1 \cdot 353(4)$ \\
$\mathrm{C} 3-\mathrm{C} 4$ & $1 \cdot 391(5)$ & $\mathrm{C} 4-\mathrm{C} 5$ & $1 \cdot 369(6)$ \\
$\mathrm{C} 19-\mathrm{C} 24$ & $1 \cdot 407(4)$ & $\mathrm{C} 19-\mathrm{C} 20$ & $1 \cdot 427(5)$ \\
$\mathrm{C} 20-\mathrm{C} 21$ & $1 \cdot 406(5)$ & $\mathrm{C} 21-\mathrm{C} 22$ & $1 \cdot 424(5)$
\end{tabular}

Bond angles $\left(^{\circ}\right)$

\begin{tabular}{lclcll}
$\mathrm{N} 2-\mathrm{Ru}-\mathrm{P}$ & $67 \cdot 47(7)$ & $\mathrm{C} 23-\mathrm{Ru}-\mathrm{P}$ & $94 \cdot 25(9)$ & $\mathrm{C} 24-\mathrm{Ru}-\mathrm{P}$ & $103 \cdot 39(7)$ \\
$\mathrm{C} 22-\mathrm{Ru}-\mathrm{P}$ & $112 \cdot 12(9)$ & $\mathrm{C} 21-\mathrm{Ru}-\mathrm{P}$ & $147 \cdot 06(10)$ & $\mathrm{C} 19-\mathrm{Ru}-\mathrm{P}$ & $132 \cdot 43(9)$ \\
$\mathrm{C} 20-\mathrm{Ru}-\mathrm{P}$ & $169 \cdot 29(8)$ & $\mathrm{N} 2-\mathrm{Ru}-\mathrm{Cl}$ & $83 \cdot 93(7)$ & $\mathrm{C} 23-\mathrm{Ru}-\mathrm{Cl}$ & $152 \cdot 92(9)$ \\
$\mathrm{C} 24-\mathrm{Ru}-\mathrm{Cl}$ & $115 \cdot 57(10)$ & $\mathrm{C} 22-\mathrm{Ru}-\mathrm{Cl}$ & $159 \cdot 37(9)$ & $\mathrm{C} 21-\mathrm{Ru}-\mathrm{Cl}$ & $121 \cdot 94(10)$ \\
$\mathrm{C} 19-\mathrm{Ru}-\mathrm{Cl}$ & $91 \cdot 19(8)$ & $\mathrm{C} 20-\mathrm{Ru}-\mathrm{Cl}$ & $95 \cdot 08(11)$ & $\mathrm{P}-\mathrm{Ru}-\mathrm{Cl}$ & $87 \cdot 25(3)$ \\
$\mathrm{N} 2-\mathrm{Ru}-\mathrm{C} 20$ & $123 \cdot 15(11)$ & $\mathrm{N} 2-\mathrm{Ru}-\mathrm{C} 19$ & $159 \cdot 41(11)$ & $\mathrm{N} 2-\mathrm{Ru}-\mathrm{C} 21$ & $98 \cdot 41(11)$ \\
$\mathrm{N} 2-\mathrm{Ru}-\mathrm{C} 23$ & $121 \cdot 58(11)$ & $\mathrm{N} 2-\mathrm{Ru}-\mathrm{C} 24$ & $158 \cdot 75(11)$ & $\mathrm{N} 2-\mathrm{Ru}-\mathrm{C} 22$ & $96 \cdot 66(11)$ \\
\hline
\end{tabular}

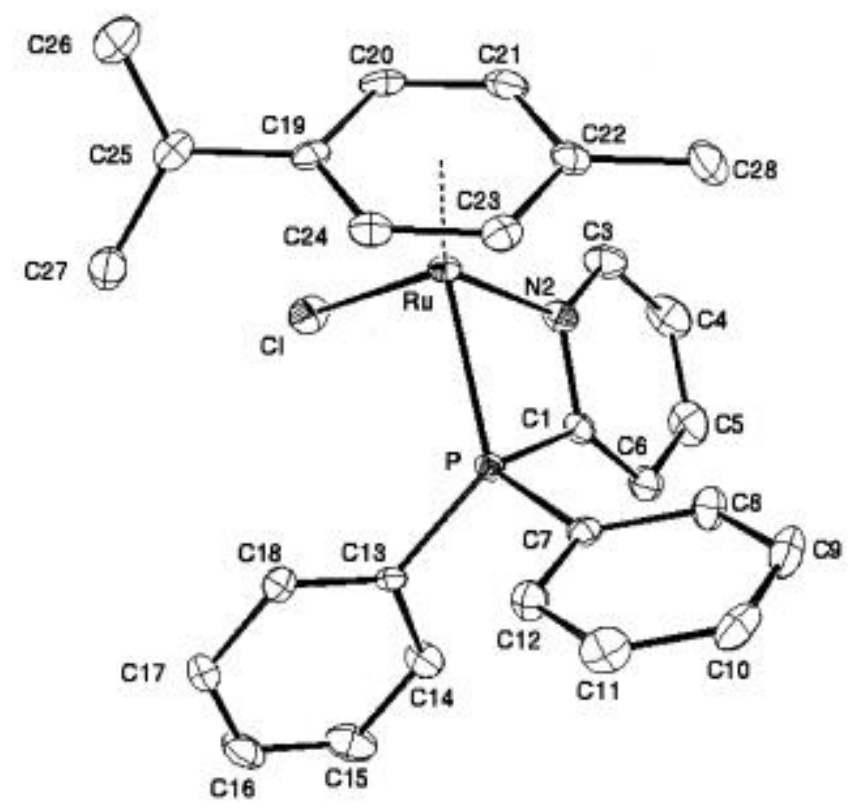

Figure 2. Molecular structure of complex $\left[\left(\eta^{6}-p\right.\right.$-cymene $)$ $\left.\mathrm{RuCl}\left(\mathrm{PPh}_{2} \mathrm{Py}\right)\right] \mathrm{BF}_{4}(2)$.

protons of isopropyl group $\left(\mathrm{HC}(\underline{\mathrm{Me}})_{2}\right)$ signals appeared as a doublet at $0.93 \mathrm{ppm}$. The ${ }^{31} \mathrm{P}$ NMR showed one signal at $21.41 \mathrm{ppm}$ due to phosphine ligand, a significant down field shift was observed after coordination to the metal as compared to free ligand $(-3.43 \mathrm{ppm})$. The far IR spectrum showed a medium intensity band for terminal stretching vibration of $v_{\mathrm{Ru}-\mathrm{Cl}}$ at $288 \mathrm{~cm}^{-1}$.

The reaction of $\left[\left\{\left(\eta^{6}-p \text {-cymene }\right) \mathrm{Ru}(\mu-\mathrm{Cl})\right\}_{2} \mathrm{Cl}_{2}\right]$ with excess of the ligand in methanol yields complexes $\mathbf{2}$ and $\mathbf{3}$ in 1:1 ratio as evidenced from ${ }^{1} \mathrm{H}$ NMR spectrum. These complexes unlike $\mathbf{1}$ are not soluble in chloroform but are soluble in acetone and dichloromethane. ${ }^{1} \mathrm{H}$ NMR spectrum of 2 shows different pattern of signals compared to the spectrum of complex 1, viz. (a) an extra triplet appears for the protons of the $p$-cymene ring. (b) Two doublets are observed at 1.16 and $1.05 \mathrm{ppm}$ for the $\mathrm{HC}(\underline{\mathrm{Me}})_{2}$ protons. We have previously reported a similar pattern of signals in the case of $p$-cymene ruthenium(II) Schiff base complexes. ${ }^{15}$ This observation could be due to the loss of planarity of the $p$-cymene ligand owing to the steric influence of the rigid $\mathrm{P}-, \mathrm{N}$ chelate ligand. The yellow crystals (complex 3) separated from complex $\mathbf{2}$ do not show any signals for the $p$-cymene moiety except well-resolved signals in the aromatic region at 8.55-6.76 ppm for phosphine ligand. This type of displacement of the $p$-cymene ring by tertiary phosphines from $\left[\left\{\left(\eta^{6}-p\right.\right.\right.$ cymene) $\mathrm{Ru}(\mu-\mathrm{Cl})\}_{2} \mathrm{Cl}_{2}$ ] is well documented. ${ }^{16}$ The ${ }^{31} \mathrm{P}-\mathrm{NMR}$ spectrum showed one sharp singlet at $1.50 \mathrm{ppm}$. The elemental data suggest the compound to be $\left[\mathrm{RuCl}_{2}\left(\mathrm{PPh}_{2} \mathrm{Py}\right)_{2}\right](\mathbf{3})$. The far IR spectrum 
taken in CsI showed a band at $280 \mathrm{~cm}^{-1}$, which was assigned to terminal $v_{\mathrm{Ru}-\mathrm{Cl}}$ stretching mode. The IR data and ${ }^{31} \mathrm{P}$ NMR spectrum suggests that the complex is trans product, otherwise one could expect a multiplet for phosphorus and two stretching bands for $\mathrm{Ru}-\mathrm{Cl}$.

\subsection{Structures of complexes $\mathbf{1}$ and $\mathbf{2}$}

An ORTEP view of the complexes $\mathbf{1}$ and $\mathbf{2}$ are shown in figures 1 and 2 . The complexes exist as half-sandwich complex with the distorted octahedral geometry around the metal centre assuming the $p$ cymene ring occupying three facial sites. The $p$ cymene ligand is $\pi$ bonded to the ruthenium atom with an average $\mathrm{Ru}-\mathrm{C}$ distance of $2.214 \AA$ and $2.212 \AA$ respectively for $\mathbf{1}$ and $\mathbf{2}$. The distance between ruthenium and the chloride ligands are almost same 2.411 and $2.397 \AA$. The average $\mathrm{C}-\mathrm{C}$ bond lengths in the $p$-cymene ring for both the complexes 1 and 2 are $1.411 \AA$ and $1.416 \AA$ respectively with alternate short and long $\mathrm{C}-\mathrm{C}$ bond lengths. The alternate bond lengths are indicative of a contribution from the cyclohexatriene resonance structure to the overall resonance hybrid. ${ }^{17}$

In complex $\mathbf{1}$, ruthenium atom is directly coordinated to phosphorus atom of the phosphine ligand with a distance of $2.356 \AA$. In complex 2, diphenyl2-pyridylphosphine ligand is bonded to the ruthenium metal in a chelating fashion forming fourmembered ring using both $\mathrm{P}$ and $\mathrm{N}$ atoms. The bond length of $\mathrm{Ru}-\mathrm{P}$ is $2.331 \AA$, which is shorter, as expected than that of $\mathbf{1}$ due to the formation of chelate ring. The bond length of $\mathrm{Ru}-\mathrm{N}(2)$ is $2 \cdot 104 \AA$ with in the range of reported compounds. The bond angles $\mathrm{P}-\mathrm{Ru}-\mathrm{Cl}(1)$ and $\mathrm{P}-\mathrm{Ru}-\mathrm{Cl}(2)$ are 90.90 and 84.83 respectively in complex $\mathbf{1}$ indicating piano stool type structure. The bond angles of $\mathrm{P}-\mathrm{Ru}-\mathrm{Cl}$ and $\mathrm{N} 2-\mathrm{Ru}-\mathrm{Cl}$ in complex 3 are $87.25^{\circ}$ and $83.93^{\circ}$ respectively. The narrow angle of $67.47^{\circ}$ for $\mathrm{N} \mathrm{Ru}-\mathrm{P}$ is expected due to the rigidity of the four-member chelating ligand.

\section{Supplementary material}

Crystallographic data for the structural analysis have been deposited at the Cambridge Crystallographic Data Centre (CCDC), CCDC No. 205909 for complex $\mathbf{1}$ and 205908 for complex 2 respectively. Copies of this information may be obtained free of charge from the Director, CCDC, 12 Union Road, Cambridge, CB2 1EZ, UK (fax: +44-1223336033; e-mail: deposit@ccdc.cam.ac.uk or www: http://www.ccdc.cam.ac.uk).

\section{Acknowledgements}

KMR thanks the Department of Science and Technology, New Delhi for financial support. RL thanks the University Grants Commission, New Delhi for financial support.

\section{References}

1. Bozec H L, Touchard D and Dixneuf $\mathrm{P} H 1989 A d v$. Organomet. Chem. 29163

2. Hauser C S, Slugove C, Mereiter K, Schmid R, Kirchner K, Xiao L and Weissensteiner W $2001 \mathrm{~J}$. Chem. Soc., Dalton Trans. 2989

3. (a) Fürstner A, Picquet $\mathrm{M}$, Bruneau $\mathrm{C}$ and Dixneuf $\mathrm{P}$ H 1998 Chem. Commun. 1315; (b) Soderberg B C G 2003 Coord. Chem. Rev. 241147

4. (a) Allardyce C S, Dyson P J, Ellis D J and Heath S L 2001 Chem. Commun. 1396; (b) Chen H, Parkinson J A, Parsons S, Coxall R A, Gould R O and Sadler P J 2002 J. Am. Chem. Soc. 124 3064; (c) Aird R E, Cummings J, Ritchie A A, Muir M, Morris R E, Chen H, Sadler P J and Jodrell D I $2002 ~ B r$. J. Cancer 86 1652; (d) Morris R E, Aird R E, del S Murdoch $\mathrm{P}$, Chen $\mathrm{H}$, Cummings J, Hughes $\mathrm{N}$ D, Parsons S, Parkin A, Boyd G, Jodrell D I and Sadler P J 2001 J. Med. Chem. 443616

5. Espinet P and Soulantica K 1999 Coord. Chem. Rev. 193-195 499

6. (a) Xie Y and James B R 1991 J. Organomet. Chem. 417 277; (b) Farr J P, Olmstead M M and Balch A L 1981 J. Am. Chem. Soc. 102 6654; (c) Farr J P, Olmstead M M, Lindsay C H and Balch A L 1981 Inorg. Chem. 201182

7. (a) Schutte R P, Rettig S J, Joshi A J and James B R 1997 Inorg. Chem. 36 5809; (b) Casares J A, Espinet P, Hernando R, Iturbe $\mathrm{G}$ and Villafane F 1997 Inorg. Chem. 3644

8. (a) Farr J P, Olmstead M M, Wood F F and Balch A L 1983 J. Am. Chem. Soc. 105 192; (b) Maisonnat A, Farr J P, Olmstead M M, Hunt C $\mathrm{T}$ and Balch A L 1982 Inorg. Chem. 21 3961; (c) Olmstead M M, Maisonnat A, Farr J P and Balch A L 1981 Inorg. Chem. 204060

9. Bennett M A and Smith A K 1982 Inorg. Synth. 2174

10. BioteX: A suite of programs for the collection, reduction and interpretation of imaging plate data, Molecular Structure Corporation (1995)

11. teXsan: Crystal Structure Analysis Package, Molecular Structure Corporation (1985 and 1992)

12. SIR92: Altomare A, Burla M C, Camalli M, Cascarano M, Giacovazzo C, Guagliardi A and Polidoro G $1994 \mathrm{~J}$. Appl. Crystallogr. 27435 
13. SHELXL-93: Program for the refinement of crystal structures, Sheldrick, G M 1993 University of Göttingen, Germany

14. 'ORTEP-II: A fortran thermal ellipsoid plot program for crystal structure illustrations'. Johnson C K 1976 ORNL-5138
15. Lalrempuia R, Mohan Rao $\mathrm{K}$ and Patrick J Carroll 2003 Polyhedron 22605

16. Bennett M A and Smith A K 1974 J. Chem. Soc., Dalton Trans. 233

17. Lahuerta P, Latorre J, Sanau M, Cotton F A and Schwotzer W 1988 Polyhedron 71311 